Int. J. Morphol.,

31(1):197-202, 2013.

\title{
Effect of Diet Contains Sesame Seed on Adult Wistar Rat Testis
}

\author{
Efecto de la Dieta con Semillas de Sésamo sobre el Testículo de la Rata Wistar Adulta
}

\author{
Amini Mahabadi J..; Hassani Bafrani H..; Nikzad, H."; Taherian, A.." \& Salehi, M.**
}

MAHABADI, J. A.; BAFRANI, H. H. \& NIKZAD, H.; TABERIAN, A. \& SALEHI, M. Effect of diet contains sesame seed on adult wistar rat testis. Int. J. Morphol., 31(1):197-202, 2013.

SUMMARY: Studies show that some antioxidants are effective in improving male infertility. According to several antioxidant compounds that exist in sesame seed, this study was designed and carried out to the effects of sesame seed diet consumption on adult male rats testis structure and sex hormones. This experimental study was carried out on 30 adults Wistar rat, $200 \mathrm{~g}$ that obtained from laboratory animal center at Kashan University of Medical Sciences. Rats were divided into experimental and control groups randomly. The control group received standard diet and experimental group received diet containing $70 \%$ standard diet and $30 \%$ sesame seed after weaning for 12 weeks. At the end of the study, testis weight and volume were measured and seminiferous tubules; lumen epithelium diameter, LH, FSH and testosterone concentrations were evaluated. Data was analyzed by SPSS software and t-test. P< 0.05 was considered to significant level. Bodyweight rats, weight and volume testis and percentage volume seminiferous tubules vessels in two groups were not significant. The mean cells number and motility of sperm in left epididym, number of cells epithelium and percentage volume of epithelial, lumen and interstitial of this tubules were extremely significant $(\mathrm{P}<0.0001)$ in the experimental group compared to control. LH concentration increased significantly in the experimental group compared to control $(\mathrm{P}<0.03)$. Sesame seed intake improved testicular parameters, fertility and sperm production in males.

KEY WORDS: Sesame seed; Testis; Rat; Sex hormones.

\section{INTRODUCTION}

Infertility is one of the medical problems in the world so that about 15-10 percent of couples have experienced some form of infertility problem (Kamali et al., 2006). It has been reported that $30 \%$ of couples infertility problems related to male, $40 \%$ to $50 \%$ related to female and $20 \%$ to $30 \%$ related to both sexes (Esmaeilzadeh et al., 2002). In recent years many efforts have been made to identify an ideal herb with strong and effective anti-metabolic effects on male fertility which already has created a serious problem. Phytoestrogens affect the reproductive system of male animals which have attracted the attention of researchers. Phytoestrogens are phenolic compounds which are similar to hormones and nonsteroidal that derived from estrogen of sesame and is found in sesame seed (Shittu, 2006).

Sesame (Sesamum indicum) is one year old seed and belongs to the Pedaliaceae family (Zavareh et al., 2008). Sesame is one of the richest dietary sources of lignan, Phytoestrogens which exist in it were known to human from the beginning of civilization and they are mixed with human food because of having many benefits for health (Thompson et al., 1991). Sesame lignan, such as: Sesamin, Sesamolin, Sesaminol, Sesamolinol, Pinorsinol, Sesamol and gammaTocopherol which are isolated from Sesamum indicum and Sesamum radiatum seeds and they have more tumorigenic, estrogenic or anti-estrogenic and antioxidant features compare with other plant species (Shittu; Jeng \& Hou, 2005; Jayalekshmy et al., 2001). In terms of phytochemical, this plant has phenolic compounds (Phenols, Sterols, Flavonoids and lignans), non-protein amino acids, cyanogenic glucoside, alkaloids, unsaturated fats and lipids with multiple double bonds, glazes, phospholipids and E, B1 and B2 vitamins. Minerals or trace elements such as calcium, iron, magnesium, zinc, copper and phosphorus exist in this plant (Konan et al., 2008). Approximate analysis of sesame seed has made it clear that the seeds contain 50$60 \%$ oil, $8 \%$ protein, $5.8 \%$ water, $3.2 \%$ crude fiber, $18 \%$ carbohydrate and $5.7 \%$ ash (Obiajunwa et al., 2005; Konan

\footnotetext{
* Anatomical Sciences Research Center, Kashan University of Medical Science, Kashan, Iran.

** Student of medicine, Student Research Committe, Kashan University of Medical Science, Kashan, Iran.
} 
et al.). Ewe atura (one of the local name in southeast Nigeria) means leaves that provide comfort and health for the body because of being useful for treatment of constipation and digestive disorders. It has been reported that boiling a mixture of roots and leaves has antiviral and antifungal activity (Krinke, 2000; Gills, 1992). Shittu et al. (2007) who evaluated the effect of fluid extract of sesame leaves on epididymal spermatocyte reserves in adult rats, concluded that sesame leaves increase fertility. Also researchers, who evaluated the effects of leaves extract of this plant on the fertility of hypoglysemic rats, found that this extract improves parameters related to the testis and increases reproductive potential in mice (Shittu et al., 2009). According to the above and lack access to adequate scientific evidence on the effect of sesame seed on testicular parameters, this study investigated the effect of sesame seeds dietary on the testes of adult male rats.

\section{MATERIAL AND METHOD}

Classification and grouping animals Thirty healthy adult Wistar rats weighing $200 \mathrm{~g}$ were obtained from animal center of Kashan University of Medical Sciences and were kept in wire cages in the animal house of the University. After infancy, they were protected and controlled under the light regime ( $12 \mathrm{~h}$ light: $12 \mathrm{~h}$ dark), at room temperature $\left(2 \pm 22^{\circ} \mathrm{C}\right)$ and humidity constant $(5 \pm 55 \%)$. During the study (12 weeks) rats were fed a diet of standard pellets and had free access to water.

Preparing food. Normal food powder of rats were collected and sieve and white sesame seeds available in the market, were powdered with domestic mill, then the powder prepared from normal food of rat $(70 \%)$ with ground sesame seeds (30\%) were mixed and turned to a pulp with water and became tubular shaped with the pastry cone then they were put in trays within a period of 2-3 days and then were dried in open air and given to rats.

\section{Qualitative and quantitative studies}

Body weight. Rats were weighing every week with a digital scale and weights were recorded. After animals were anesthetized and incision made on the chest and abdomen, first, blood sample was taken from the heart and their testes were removed.

Weight and testicular volume. Both testes were dissected carefully and all the fat was removed. Testicular weight was measured with a sensitive scale and their volume was measured with water displacement in a $10 \mathrm{ml}$ cylinder.
Motility and sperm count in the epididymis. After anesthesing, scrotal incision was performed and testis and epididymis were appeared. The left epididymis was dissected and transferred to HAMS F10 culture and with a few incisions in the head, trunk and tail of the epididymis, provides sperm to come out and after 20 min, culture containing microliters of sperm were placed on slides then sperm parameters (count and mobility) were measured.

Measurement of serum hormones. FSH and LH concentrations were measured by using the ELISA technique in samples of 50 microliters. Evaluation of serum testosterone was performed by using the ChemoLuminance.

\section{Testicular tissue evaluation}

Counting the spermatogenetic cells. For this purpose 4 sections have been studied randomly, and from each section, 5 spermatogenetic duct in testes (to increase the accuracy of counting) have been chosen which were in stages VII and VIII of the cell cycle and had a perfectly circular cross section (3). Cell counting was done by using a Zeiss optical microscope with a magnification of 40X. In each duct spermatogonia cells, spermatocyte in pacyten stage, round spermatid and elongated spermatid have been counted and after determining the average cell in a duct of one group, were compared with cells of other group.

Determining the volume percent. For this purpose point-counting was used for the volume percent of epithelium, interstitial space and seminiferous tubule lumen. These were measured by using a Zeiss optical microscope with $10 ¥$ magnification. To determine the volume percent of the components of testicular tissue, 6 sections were used in two perpendicular directions to each other with equal intervals and non-overlapping.

Measuring the diameter of the seminiferous tubule. For measuring this parameter, Zeiss optical microscope with Eye Piece micrometer was used which had X10 magnification calibrated by Stage Micrometer. Desired parameters (seminiferous tubule diameter) thirty, seminiferous tubule (6 sections and each section with 5 tube) with circular or nearly circular cross section were measured in each testis (Krinke).

Statistical analysis. The data were prepared as Mean \pm SEM and statistical analysis was performed by using student,s t-test and one way ANOVA analysis. $\mathrm{P}<0.05$ was considered to be significant. 


\section{RESULTS}

This study was done on 30 adult male Wistar rats weighing $190-210 \mathrm{~g}$. The rats were randomly divided into control and experimental groups. Control group used normal diet and experimental group fed $70 \%$ normal diet and $30 \%$ sesame seed after infancy for 12 weeks. Significant differences were not observed in animal body weight, testicular weight and volume in both control and experimental groups (Table I). Sperm number and mobility in left epididymis significantly increased in experimental group compared with control group (Table I). LH levels significantly increased in experimental group compared to controls but significant changes in FSH and testosterone levels were not observed in both groups (Table I). In This study spermatogonia cells, primary spermatocyte, spermatid and spermatozoa increased significantly in both right and left testes of the experimental group compared to control group $(\mathrm{P}<0.0001)$. Changes in volume percent of epithelium and lumen in both testes significantly increased in experimental groups compared to control group and interstitial space of seminiferous tubules significantly decreased in experimental group compared with the control group $(\mathrm{P}<0 / 0001)$, also in this study, changes of were vascular volume detected non-significant in both groups. According to the results of this study, the diameter of seminiferous tubules with a probability level ( $\mathrm{P}<0 / 0001)$ in both right and left testes of the experimental group showed a significant increase compared with the control group (Table I).

Table I. Various parameters in control and experimental groups of male rats.

\begin{tabular}{|c|c|c|c|}
\hline Variable & $\begin{array}{l}\text { Control group } \\
\text { (Mean } \pm \text { SEM) }\end{array}$ & $\begin{array}{c}\text { Experimental group } \\
\text { (Mean } \pm \text { SEM) }\end{array}$ & P-value \\
\hline Body weight (g) & $195.88 \pm 7.67$ & $194.42 \pm 8.04$ & 0.89 \\
\hline Testis weight $(\mathrm{g})$ & $0.026 \pm 1.45$ & $1.5025 \pm 0.029$ & 0.235 \\
\hline Testis volume $\left(\mathrm{cm}^{3}\right)$ & $5.672 \pm 0.242$ & $5.485 \pm 0.244$ & 0.599 \\
\hline Sperm number $\left(\mathrm{x} 10^{6}\right)$ & $62.14 \pm 3.91$ & $74.23 \pm 2.52$ & 0.017 \\
\hline Sperm motility (\%) & $57.86 \pm 3.77$ & $72.31 \pm 2.98$ & 0.006 \\
\hline LH (IU/L) & $2.7 \pm 0.29$ & $3.5 \pm 0.22$ & 0.031 \\
\hline FSH (mIU/L) & $3.9 \pm 0.44$ & $3.3 \pm 0.28$ & 0.27 \\
\hline $\mathrm{T}(\mathrm{nmol} / \mathrm{L})$ & $10.88 \pm 2.9$ & $8.45 \pm 2.9$ & 0.57 \\
\hline $\mathrm{n}$ of Spermatogonia/Tubule & $40.49 \pm 4.62$ & $50.22 \pm 5.18$ & $<0.0001$ \\
\hline $\mathrm{n}$ of Primary spermatocyte/Tubule & $47.7 \pm 5.45$ & $59.86 \pm 6.46$ & $<0.0001$ \\
\hline n of Spermatid/Tubule & $114.66 \pm 13.82$ & $149.15 \pm 17.3$ & $<0.0001$ \\
\hline $\mathrm{n}$ of Spermatozoa/Tubule & $116.28 \pm 12.84$ & $146.64 \pm 16.12$ & $<0.0001$ \\
\hline Volumetric density of the epithelium (\%) & $48.76 \pm 0.515$ & $55.82 \pm 0.47$ & $<0.0001$ \\
\hline Volumetric density of lumen (\%) & $13.04 \pm 0.26$ & $14.31 \pm 0.22$ & $\langle 0.0011\rangle$ \\
\hline Volumetric density of Interstitial space (\%) & $37.7 \pm 0.66$ & $29.14 \pm 0.51$ & $<0.0001$ \\
\hline Volumetric density of vessels (\%) & $0.615 \pm 0.14$ & $0.795 \pm 0.11$ & 0.337 \\
\hline Tubular diameter $(\mu \mathrm{m})$ & $210.62 \pm 1.62$ & $248.42 \pm 1.82$ & $<0.0001$ \\
\hline
\end{tabular}

Results expressed in mean \pm S.E.M (Standard Error of Mean). $n=15$.

\section{DISCUSSION}

In this study, the number of spermatogonia cells, primary spermatocyte, spermatid and spermatozoa increased significantly in both right and left testes of the experimental group compared to control group ( $\mathrm{P}<0.0001)$. Statistical increase in cells can be attributed to mitosis and meiosis division and factors affecting cytokinesis (Berne \& Levy, 1993). The results of this study are in accordance with the study of Shittu et al., (2008) who found that the extract of sesame leaves, increases the number of spermatogonia cells of epithelium seminiferous tubules in the experimental group 
compared to control, this high number is due to increased primary spermatocyte which is the result of increasing proliferation of stem cells or increasing in spermatogenesis due to large mass of epithelial in these tubules. Shittu et al. (2009) concluded that the number of cells in seminiferous tubules significant increased in diabetic mice compared with control group which are consistent with the results of this study but these researchers examined the effect of fluid extract of sesame leaves on diabetic rats whereas the sesame seeds were used in this study.

According to the results obtained in this study, the volume percent of epithelium and lumen significantly increased in testes of experimental group compared with control group $(\mathrm{P}<0.0001)$ and interstitial space of seminiferous tubules significantly decreased in the experimental group compared with the control group $(\mathrm{P}<0.0001)$ but in this study, vascular volume percent was detected non-significant in both groups. Study of Shittu et al., (2009) showed that in hypoglycemic rats which were receiving fluid extract of sesame leaves, the average lumen volume percent were increased and interstitial cells volume percent of seminiferous tubules of testis were decreased (Huang et al., 1987) which is consistent with results of this study but it is noteworthy that these researchers studied the sesame leaves extract dietary on rats. It is expected that sesame will stimulate spermatogenesis mechanisms via such as epithelial proliferation and increased lumen and tubular thickness, especially from stages V to VII of spermatogenesis (Shittu et al., 2009).

According to the results of this study, highly significant changes were observed in diameter of seminiferous tubules with a probability level $(\mathrm{P}<0 / 0001)$ in the testes in the experimental group compared with control group. FSH level is the main factor in the growth of seminiferous tubules and testicular size, also Ribnicky et al., (2006) and Shittu et al. (2008) who studied on the effect of sesame leaves on rats, found that FSH and testosterone are involved as synergistic in the process spermatogenesis (Berne \& Levy) which is inconsistent with our results because the concentrations of these two hormones in this study did not show significant changes, in addition normal testicular growth and development requires the transcription of DNA molecules and proteins function in the testes. Changing the diameter of these tubules may be for two reasons: A) Increased androgens, increase protein synthesis of seminiferous tubules (Hadley, 1996). B) Increased number of stem cells of seminiferous tubules cause a change in diameter. According to this results, Shittu et al., (2009) showed that consumption of fluid extract of sesame leaves increased the mean diameter of seminiferous tubules in the experimental group (consumer extract) compared to the control group (not taking the extract) $(\mathrm{P}<0 / 05)$.
Sesame is very useful for humans due to the economic and medicinal value. These seeds are rich as minerals and trace minerals; vitamins and antioxidant lignan (phytoestrogens) and can improve the fertility potential of male reproductive tract (Shittu et al., 2008). We know that the beneficial effects of high intake of fruits and vegetables that just do not affect different conditions of body's metabolic disease (Such as diabetes mellitus, obesity, heart disease and cancer) but also has positive effects on person reproductive tract (Shittu et al., 2008). Many antioxidant or non- antioxidant phytochemical compounds with additive or synergistic activities of various compounds found in fruits such as alpha-linolenic, various phenolic compounds (sesamol, sesamin) and fibers exist in sesame seed. Thus, it seems that estrogen receptor-alpha is useful in regulating reproductive physiology estrogen, including components of behavior compared to the estrogen receptor beta (Zaneveld \& Polakoski, 1977).

Significant increase was observed in LH levels in the experimental group compared to controls $(\mathrm{P}<0.03)$. But significant changes in FSH and testosterone levels were not observed in both groups. Shittu et al., (2008) who studied the sesame leaves extract on rats found that sesame phytoestrogen lignans can stimulate testosterone aromatization to estradiol, or convert to dihydrotestosterone, so it can be concluded that decreasing the concentrations of testosterone, is because of converting it to estradiol which is done by aromatase and reductase enzyme and sesame lignans. Huang et al., concluded that less than $25 \%$ concentration of testicular testosterone is sufficient to protect all stages spermatogenesis.

According to the study of Shittu et al. (2008), FSH concentration decreased in consumer of high dose liquid extract of sesame leaves group compared with control group and it does not match to our results, the result differences obtained from these studies with our results are in the type of diet (extract of sesame leaves), type of rats and duration of using diet. However, FSH has a synergistic effect with testosterone hormone and stimulating synthesis of the androgen receptor at the receptor level. Plant \& Marshall (2001) found that treating the removed pituitary rats with FSH stimulates spermatogenesis with androgen binding protein $(\mathrm{ABP})$ in testis and epididymis.

In the present study, sperm number in the left epididymis significantly increased in experimental group compared to the control group $(\mathrm{P}<0.0172)$, also sperm mobility in the left epididymis was significantly higher in experimental group compared to the the control group $(\mathrm{P}<0.0064)$. Obtained results were consistent with the study of Shittu et al., (2008) who obtained the number of cells and spermatozoa from the caudate of epididymis with Zanold and Pockashi method (Zavareh et al.), the researchers found that the number 
of sperm in the caudate of epididymis significantly increased, this increase may be due to increased spermatocyte which is the result of increased stem cell proliferation or increase in spermyogenesis (Shittu et al., 2008). Also Shittu et al., (2009) found that liquid extract of sesame leaves, increases sperm mobility, which may be due to antioxidant properties of sesame on free radicals that are likely consistent with the our results.

Experimental rats and the control group did not show any significant increase in body weight which was similar to the study of Awoniyi et al., (1997) who evaluated the effect of phytoestrogens on spermatogenic potential in rats. According to the study of Shittu et al., $(2009,2007)$ who suggested that the fluid extract of sesame leaves significantly increase the weight of rats, which was inconsistent with the results of this study. The sesame seed is used in this study, and giving this diet for a long time may increase body weight.

Weight and volume of testis showed no significant changes in all groups. Ashamu et al., (2010) studied the ethanolic effect of sesame seed extract and vitamin $\mathrm{C}$ on fertility of Wistar rats, concluded that significant differences were observed in testicular weight in the vitamin $\mathrm{C}$ consumer group (as one of the antioxidants in sesame seed) compare with control group but the group which used ethanolic extract of sesame extract alone and received it with vitamin $\mathrm{C}$ simultaneously, testicular weight was more in comparison with control group. The increase in testicular weight can be attributed to a combination of high fat and calories of seeds, which researchers showed that using vitamin $\mathrm{C}$ alone had no effect on testicular weight and volume. It is worth noting that the researchers studied the ethanolic effect of sesame extract and vitamin $\mathrm{C}$ on the parameters associated with testis. Kuiper et al., (1997) who evaluated the differences between the ligand binding to estrogen receptors alpha and beta in the testis, found that testis weight loss in experimental group comparison with the control group is due to its estrogenic action of sesame lignin which is depending on estrogen receptors binding (alpha and beta) in the testis compare with receptor in epididymis which is inconsistent with the results of our study. Thus, estrogen or its receptor is important for normal functioning of the reproductive system of different species. Whereas the study of Shittu et al., (2009) showed that weight and size of testis in rats which have used the fluid extract of sesame leaves, had significant differences compared with control groups. It seems that the cause of differences in our results compared with the results of study of Shittu et al., $(2007,2009)$ may be the use of liquid extract of sesame leaves, whereas we used sesame seed in this study, also, the rat race in these two studies were different. Oral administration of seed for long-term may cause significant changes in testicular weight and volume, also it is likely that significant changes will observed by increasing the number of tested animals.

\section{CONCLUSION}

This study shows that sesame seed increase LH and improves spermatogenesis process, also, the seed oil has no effect on body weight.

\section{ACKNOWLEDGEMENTS}

This article is approved by Kashan University of Medical Sciences as the research project with the title "Effect of diet contain sesame seed on Adult Male Wistar Rat Testis". Authors sincere appreciate and thank to all colleagues in the research center Anatomy, department of Histology and Pathology of Kashan University of Medical Sciences.

MAHABADI, J. A.; BAFRANI, H. H. \& NIKZAD, H.; TABERIAN, A. \& SALEHI, M. Efecto de la dieta con semillas de sésamo sobre el testículo de la rata Wistar adulta. Int. $\boldsymbol{J}$. Morphol., 31(1):197-202, 2013.

RESUMEN: Estudios demuestran que algunos antioxidantes son eficaces en la mejora de la infertilidad masculina. Debido a la presencia de varios compuestos antioxidantes que existen en la semilla de sésamo, este estudio fue diseñado y realizado para evaluar los efectos de su consumo sobre la estructura testicular y las hormonas sexuales de ratas macho adultas. Se utilizaron 30 ratas Wistar adultas de $200 \mathrm{~g}$ obtenidas desde el centro laboratorio animal de Kashan University of Medical Sciences. Las ratas se dividieron en grupos experimental y de control. El grupo control recibió una dieta estándar y el grupo experimental una dieta que contenía $70 \%$ de dieta estándar y 30\% de semillas de sésamo, después del destete durante 12 semanas. Al final del estudio, se midieron el peso y volumen de los testículos y túbulos seminíferos, diámetro luminal epitelial, y las concentraciones de LH, FSH y testosterona. Los datos fueron analizados mediante ttest con el programa SPSS. Fue considerado significativo un valor $\mathrm{P}<0,05$. El peso corporal de las ratas, peso y volumen testicular, $\mathrm{y}$ el porcentaje volumétrico de los túbulos seminíferos en los dos grupos no fue significativo. La media del número de células y la motilidad de los espermatozoides en epidídimo izquierdo, número de células del epitelio y porcentaje volumétrico del epitelio, y lumen intersticial de los túbulos fueron significativos $(\mathrm{P}<0,0001)$ en el grupo experimental en comparación con el control. La concentración de LH aumentó significativamente en el grupo experimental en comparación con el control $(\mathrm{P}<0,03)$. La ingesta de semillas de sésamo mejora de los parámetros testiculares, la fertilidad y la producción de espermatozoides en machos.

PALABRAS ClAVE: Semillas de sésamo; Testículo; Rata; Hormonas sexuales. 


\section{REFERENCES}

Ashamu, E.; Salawu, E.; Oyewo, O.; Alhassan, A.; Alamu, O. \& Adegoke, A. Efficacy of vitamin $\mathrm{C}$ and ethanolic extract of Sesamum indicum in promoting fertility in male Wistar rats. $J$. Hum. Reprod. Sci., 3(1):11-4, 2010.

Awoniyi, C. A.; Roberts, D.; Chandrashekar, V.; Veeramachaneni, D. N.; Hurst, B. S.; Tucker, K. E.; et al. Neonatal exposure to coumestrol, a phytoestrogen, does not alter spermatogenic potential in rats. Endocrine, 7(3):337-41, 1997.

Berne, R. M. \& Levy, M. N. Physiology. $3^{\text {rd }}$ ed. St. Louis, Mosby, 1993. pp.950-9.

Esmaeilzadeh, S.; Farsi, M. \& Nazari, T. The cause of infertility frequency in the patients referring to Babol township Fatemeh Zahra Infertility Center from May 1996 to May 1998. J. Mazandaran Univ. Med. Sci., 12(35):29-34, 2002.

Gills, L. S. Ethnomedical uses of plants in Nigeria. Benin City, Uniben Press, 1992. p.212.

Hadley, E. M. Endocrinology. $4^{\text {th }}$ ed. New Jersey, Prentice Hall, 1996.

Huang, H. F.; Marshall, G. R.; Rosenberg, R. \& Nieschlag, E. Restoration of spermatogenesis by high levels of testosterone in hypophysectomized rats after long-term regression. Acta Endocrinol. (Copenh), 116(4):433-44, 1987.

Jayalekshmy, A.; Arumugham, C. \& Suja, K. P. Process for extraction of antioxidants from sesame seed/cake. US Patent. Appl., 60/ 04.004, 2001.

Jeng, K. C. G. \& Hou, R. C. W. Sesamin and Sesamolin: Nature's Therapeutic Lignans. Curr. Enzym. Inhib., 1(1):11-20, 2005.

Kamali, M.; Kashfi, F.; Baghestani, A. R.; Kashani, H.; Tavajohi, S. H. \& Amirchaghmaghi, E. The epidemiologic survey on causes of infertility in patients referred to Royan Institute. Med. J. Tabriz. Univ. Med. Sci., 28(1):103-5, 2006.

Konan, A. B.; Datté, J. Y. \& Yapo, P. A. Nitric oxide pathway-mediated relaxant effect of aqueous sesame leaves extract (Sesamum radiatum Schum. \& Thonn.) in the guinea-pig isolated aorta smooth muscle. BMC Complement Altern. Med., 8:23, 2008.

Krinke, G. I. The handbook of experimental animals: The laboratory rat. Chapter 9. London, Academic Press, 2000. pp.145-52.

Kuiper, G. G.; Carlsson, B.; Grandien, K.; Enmark, E.; Häggblad, J.; Nilsson, S.; et al. Comparison of the ligand binding specificity and transcript tissue distribution of estrogen receptors alpha and beta. Endocrinology, 138(3):863-70, 1997.

Obiajunwa, E. I.; Adebiyi, F. M. \& Omode, P. E. Determination of Essential Minerals and Trace Elements in Nigerian Sesame Seeds, Using TXRF Technique. Pakistan J. Nutr., 4(6): 393-5, 2005.
Plant, T. M. \& Marshall, G. R. The functional significance of FSH in spermatogenesis and the control of its secretion in male primates. Endocr. Rev., 22(6):764-86, 2001.

Ribnicky, D. M.; Poulev, A.; Watford, M.; Cefalu, W. T. \& Raskin, I. Antihyperglycemic activity of Tarralin, an ethanolic extract of Artemisia dracunculus L. Phytomedicine, 13(8):550-7, 2006.

Shittu, L. A. J. The effect of the aqueous crude leaves extract of Sesamum radiatum compared to Mesterolone (proviron) on the adult male Sprague Dawley rats testis and epididymis. MSc Dissertation. Lagos State University, College of Medicine, Ikeja, Nigeria, 2006.

Shittu, L. A. J.; Bankole, M. A.; Oguntola, J. A.; Ajala, O.; Shittu, R. K.; Ogundipe, O. A.; et al. Sesame leaves intake improve and increase epididymal spermatocytes reserve in adult male Sprague Dawley rat. Sci. Res. Essay, 2(8):319-24, 2007.

Shittu, L. A. J.; Shittu, R. K.; Adesite, S. O.; Ajala, M. O.; Bankole, M. A.; Benebo, A. S.; et al. Sesame radiatum Phytoestrogens Stimulate Spermatogenic Activity and Improve Sperm Quality in Adult Male Sprague Dawley Rat Testis. Int. J. Morphol., 26(3):643-52, 2008.

Shittu, L. A. J.; Shittu, R. K.; Ogundipe, O.; Tayo, A. O. \& Osunubi, A. A. A. Hypoglycaemia and improved testicular parameters in Sesamum radiatum treated normo-glycaemic adult male Sprague Dawley rats. Afr. J. Biotechnol., 8(12):2878- 86, 2009.

Thompson, L. U.; Robb, P.; Serraino, M. \& Cheung, F. Mammalian lignan production from various foods. Nutr. Cancer, 16(1):4352, 1991.

Zaneveld, L. J. D. \& Polakoski, K. L. Collection and physical examination of the ejaculate. In: Hafez, E. S. E. (Ed.). Techniques of Human Andrology. Amsterdam, North Holland Biomedical Press, 1977. pp.147-56.

Zavareh, M.; Hoogenboom, G.; Rahimian, M. H. \& Arabd, A. A decimal code to describe the growth stages of sesame (Sesamum orientale L.). Int. J. Plant Prod., 2(3):193-206, 2008.

\section{Correspondence to:}

Amini Mahabadi J.

Anatomical Sciences Research Center

Kashan University of Medical Science

Kashan

IRAN

Email: hhassanib@gmail.com

Received: 28-08-2012

Accepted: 15-11-2012 